\title{
Laboratory and Field Studies of Myomys daltoni Reproductive Parameters
}

\author{
P. A. ANADU
}

Anadu P. A., 1978: Laboratory and field studies of Myomys daltoni reproductive parameters. Acta theriol., 23, 35: 519-526. [With 1 Fig. \& 2 Tables].

Reproductive characteristics of Myomys daltoni (Thomas) are described in terms of the age at sexual maturity, litter size, number of litters and pre-natal mortality, and are discussed in relation to the observed low population density in the study areas. Mice attain sexual maturity at about 18-22 weeks of age at an average body weight of $26.2 \mathrm{gm}$ (females) or $27.5 \mathrm{gm}$ (males). The mean litter size for wild caught mice is 5.55 (range $1-7$ ). Some mice probably produce 5-6 litters annualy. Pre-natal mortality was observed in seven out of 15 pregnancies with embryonic losses totaling 23.6\%. Full reproductive vigour is achieved during the second breeding season, but the major contributors of offspring are those females which breed towards the end of the wet season.

[Dept. Zool., Univ. Ibadan, Ibadan, Nigeria].

\section{INTRODUCTION}

Dalton's mouse, Myomys daltoni (Thomas) occurs throughout West Africa, except east of the Lower Niger; it ranges from the forest edge to the Sudan savanna zone (R o s e v e a r, 1969). From November 1970 to June 1973 ecological studies were conducted on populations of this mouse in the grassland areas of Olokemeji Forest Reserve $\left(7^{\circ} 26^{\prime} \mathrm{N}\right.$, $3^{\circ} 33^{\prime} \mathrm{E}$ ) and Eruwa $\left(7^{\circ} 30^{\prime} \mathrm{N}, 3^{\circ} 28^{\prime} \mathrm{E}\right.$ ) (An adu, 1974). During this study, and subsequent work on a laboratory colony collected from Olokomeji and from Aje-Pero near Fashola $\left(7^{\circ} 54^{\prime} \mathrm{N}, 3^{\circ} 47^{\prime} \mathrm{E}\right)$, data were collected on the reproductive biology of this species.

Within its geographical range $M$. daltoni appears to form a sizeable component of the small rodent fauna. A n a d u (1974) showed that it made up about one-third of all the mice caught in his study area, while H a p pold (1975) also reported that it was one of the commonest species caught in other savanna areas of Western Nigeria. The biology [519] 
of this mouse has however remained neglected and there is presently no published information on its breeding habits. The data presented here provide information on the age of mice at sexual maturity, litter size, number of litters per year, and pre-natal mortality. These parameters are evidently useful in estimating the reproductive output of the population.

\section{MATERIALS AND METHODS}

The sampling technique and the study area have been described in a separate paper (A $\mathrm{nadu}$, in press). The breeding technique is the same as was described for Mus musculoides Temminck (An a du, 1976). A slight modification in the feeding regime, however, is that since 1975 mice have been fed on crushed commercial mouse cubes enriched with Dicalcium phosphate (Calcium hydrogen orthophosphate) and a vitamin/trace elements supplement, while freshly sprouted cereals were supplied once a week. In addition, intact cubes were provided in order to satisfy mouse urge to hoard and to hold food in their paws while feeding.

The laboratory colony was started with ten live-trapped young adults. Three of these (two females and one male) were caught at Olokemeji in 1971 while the rest (four females and three males) were collected from Aje-Pero in 1975. Mice bred readily and a total of 239 individuals from 76 litters were raised in captivity.

\section{RESULTS}

\subsection{Breeding Season}

Details of breeding activity in the wild population have been published elsewhere (Anadu, in press). Breeding took place virtually in all months of the year, but there were marked peaks of activity at the beginning of the year (late February to April) and towards the end of the rainy season (September to November, extending to December in 1972).

\subsection{Age at Sexual Maturity}

The age at sexual maturity in wild caught mice was determined by the method of Leslie, et al. (1945). The median body weights at sexual maturity were: females; $26.2 \mathrm{gm}$, range $25.1-27.3 \mathrm{gm}(P=0.95)$, males; $27.5 \mathrm{gm}$, range $26.4-28.6 \mathrm{gm}(P=0.95)$. The lightest live-trapped female with a perforate vagina weighed $25 \mathrm{gm}$, and one autopsied specimen was pregnant at $23 \mathrm{gm}$, but all embryos were resorbing. The youngest scrotal male caught weighed $25 \mathrm{gm}$. Both sexes therefore reached sexual maturity at similar body weights. Estimates of age made from the growth rate of laboratory reared animals (A nadu, in preparation) suggested that mice attained these average weights at about $18-22$ weeks of age. 


\subsection{Litter Size}

Mean litter size based on 18 pregnancies conceived in the field was 5.55 (Table 1). The range of implanted embryos was three to ten, with five as the frequent number. A clear correlation could not be established between maternal age and litter size. Fig. 1 however suggests that larger litters were produced towards the end of the year by both young and old adults but with older mice tending to produce even bigger litters.

Table 1

Litter size and implantation sites in wild caught pregnant female Myomys daltoni. Data pooled for Olokemeji and Eruwa.

\begin{tabular}{|c|c|c|c|}
\hline $\begin{array}{l}\text { Litter } \\
\text { size }\end{array}$ & $\begin{array}{c}\text { Implan } \\
\text { Right }\end{array}$ & $\begin{array}{l}\text { site } \\
\text { Left }\end{array}$ & $\begin{array}{l}\text { Observed number } \\
\text { of females }\end{array}$ \\
\hline \multirow[t]{2}{*}{3} & 2 & 1 & 1 \\
\hline & 1 & 2 & 2 \\
\hline \multirow[t]{2}{*}{4} & 2 & 2 & 1 \\
\hline & 1 & 3 & 2 \\
\hline \multirow[t]{4}{*}{5} & 4 & 1 & 1 \\
\hline & 3 & 2 & 1 \\
\hline & 2 & 3 & 1 \\
\hline & 1 & 4 & 2 \\
\hline 6 & 1 & 5 & 1 \\
\hline 7 & 3 & 4 & 2 \\
\hline 8 & 4 & 4 & 1 \\
\hline & 3 & 5 & 2 \\
\hline 10 & 5 & 5 & 1 \\
\hline $\begin{array}{l}\text { Total } \\
\text { Mean }\end{array}$ & 41 & 59 & $\begin{array}{l}18 \\
5.55\end{array}$ \\
\hline
\end{tabular}

Note: (1) Left, right refer to the uterine horns.

(2) No mouse was found with less than 3 embryos or with 9 embryos.

The mean litter size for the laboratory colony was 3.93 . The range was one to seven with four as the modal number. Student's $t$-test showed that the difference between the mean litter sizes in the wild and captive - bred females was highly significant $(t=3.21$ with 21 degrees: of freedom; $P<0.01$ ). The laboratory data, however, refer to the number of young at birth and do not take into account intra-uterine mortalities which probably acount for the disparity.

No significant difference was observed in the distribution of embryos between the uterine horns $\left(\chi^{2}=3.24\right.$ with 1 degree of freedom; $0.10>\mathrm{P}>0.05$ ).

\subsection{Number of Litters}

In the laboratory, $M$. daltoni bred throughout the year with mice producing up to nine litters in succession. That it is polyoestrous in: 
nature is indicated by the capture of five pregnant nursing mice. The occurrence of lactation in early pregnancy in these mice also implies mating at postpartum oestrus, a fact which was confirmed in the laboratory population. It is therefore postulated that, given a pregnancy duration of $21-37$ days (A $n$ a d u, unpublished data), wild females

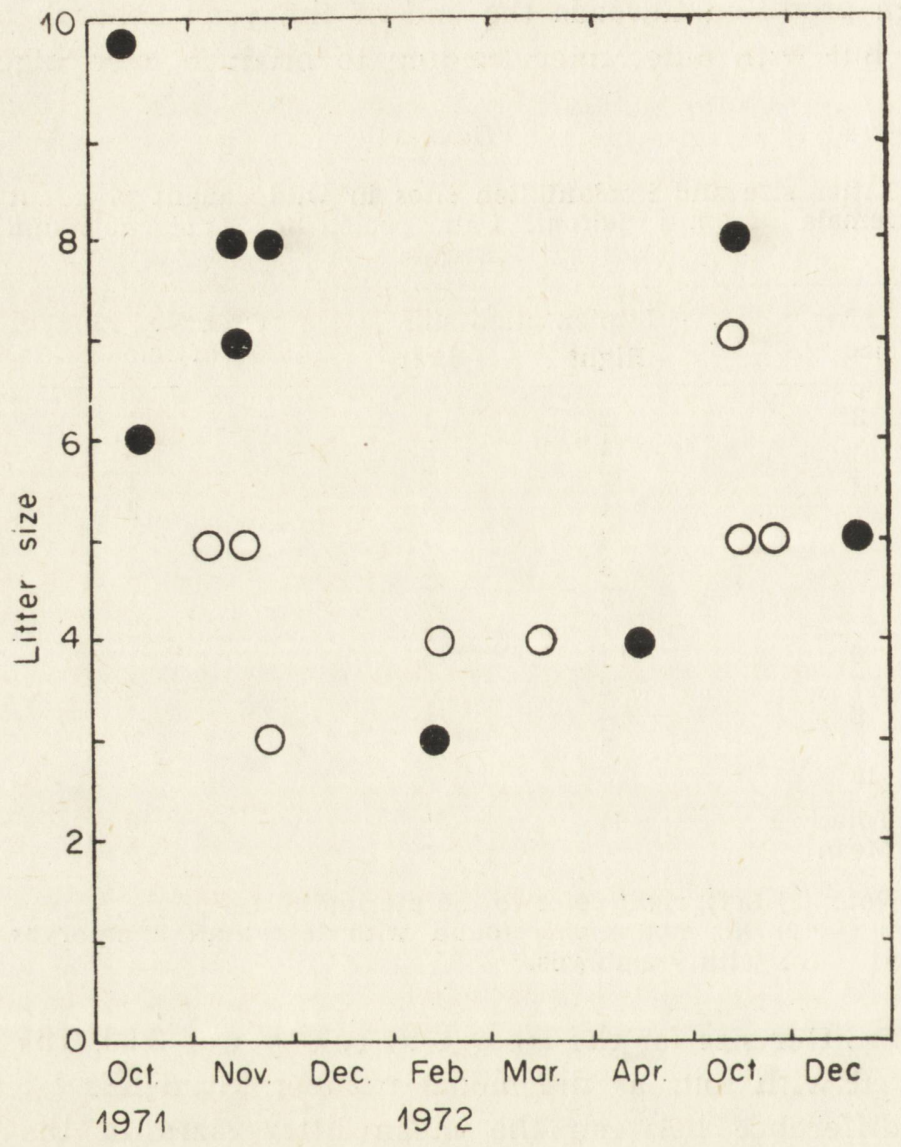

Fig. 1. Relationship between litter size, maternal age, and time of the year. Maternal age was asessed from pattern of molar wear and the occurrence of placental scars.

○ Young (non-parous) adults, $(<9$ months old); - Old (parous) adults, $(>9$ months old).

can rear two to three litters in succession during the two annual periods of intense breeding activity. Thus a female which took part in these peak breeding seasons could produce five to six litters within a year. Estimates of the minimum number of previous litters based on counts of visible placental scars indicated that about $25 \%$ of breeding females had produced two to three litters. 


\subsection{Pre-natal Mortality}

In utero resorption of embryos was observed in three pregnant females (Table 2). Two of them were parous old adults one of which had seven, and the other ten embryos; in the former female two embryos, and in the latter all ten embryos were resorbing. The third female, a precocious sub-adult already referred to elsewhere, had five resorbing embryos. A comparison of the number of in utero embryos and the number of obvious corpora lutea showed that only four embryos had been lost in four separate pregnancies. Thus the total embryonic mortality in this sample was 21 representing $23.6 \%$ of total observed embryos.

\section{DISCUSSION}

Elsewhere (A n adu, in press) it has been reported that $M$. daltoni has a low population density ranging from a minimum of $2.6 /$ ha to $17.1 / \mathrm{ha}$. This is consistent with the widespread observation that many animals of the humid tropics have a relatively low population density when compared with their temperate counterparts. This scarcity has been attributed to the presence of numerous species in tropical habitats (e.g. O we n, 1966). Intense competition and complex trophic interrelationships are thought to exert a damping effect and thus prevent any single species from reaching plague densities.

The reproductive characteristics of $M$. daltoni however, suggest that there may be inherent biological mechanisms which could contribute to the maintenance of a low population density in some small mammals.

The riean litter size and range of implanted embryos for wild populations of $M$. daltoni are among some of the highest recorded in small tropical rodents and compare well with some temperate species (Table 2). But the time taken to attain sexual maturity $\left(4^{1 / 2}\right.$ to $5^{1 / 2}$ months) is also one of the longest and would favour the production of only a few, albeit large litters during the breeding life of a female. Other factors which could contribute to lowered reproductive output are the occurrence of delayed implantation (A $\mathrm{nad} u$, in preparation), and intra-uterine mortalities.

The environment too exerts a strong regulatory effect in the following manner. The contribution of a female to the production of offspring depends on the time of year she is born and, of course, her duration of residence. The major production of young occurs towards the end of the wet season, presumably because food is more abundant at this time than at the beginning of the year (mid-dry season). Not only is intense 
breeding effort sustained for a longer period (3-4 months) but larger litters are produced. Analysis of age structure (A $n$ a d u, 1974) indicated that a high proportion of breeders at this time of the year were young adults born at the beginning of the year. Since older surviving females which have reached a second breeding season at the end of the rains (having bred at the beginning of the year upon attainment of sexual

Table 2

Correspondence between number of active corpora lutea and the number of in utero embryos in Myomys daltoni.

\begin{tabular}{cc}
\hline $\begin{array}{c}\text { Number of visible } \\
\text { corpora lutea }\end{array}$ & $\begin{array}{c}\text { Number of in utero } \\
\text { embryos }\end{array}$ \\
\hline 10 & $10+(10)$ \\
7 & $6^{*}+(5)$ \\
5 & $5+3^{*}$ \\
4 & $5^{*}$ \\
6 & $7^{+}(2)$ \\
7 & 8 \\
8 & $8^{*}$ \\
9 & 4 \\
4 & 4 \\
4 & 4 \\
4 & 7 \\
7 & 8 \\
8 & 5 \\
5 & 5 \\
5 & 89 \\
93 &
\end{tabular}

* embryonic losses;

+ litters in which intra-uterine mortality occurred; the number of embryos resorbing is shown in parenthesis. Total embryonic loss $=21(23.6 \%$ of total observed embryos).

Note: Three pregnancies, in which there was doubt about the number of active corpora lutea, have been excluded from this Table.

maturity) tend to produce larger litters than these young mice, it is reasonable to assume that full reproductive vigour is not attained until mice are almost one year old. But only a few mice would ever live this long. Thus the population is prevented from breeding at its maximum capacity and the only major contributors of offspring are females born at the beginning of the wet season.

The relatively low population density in $M$. daltoni therefore appears to be maintained by a combination of extrinsic and intrinsic factors (as 
revealed by its reproductive characteristics, which are typically those of a $K$-adapted species). Further work is required to determine the extent of this phenomenon in small rodent populations of the humid tropics.

Acknowledgement: I wish to thank Dr D.C.D. Happold for his helpful advice and encouragement during the early phase of this work. Special thanks to to Dr B. L. Fetuga for loaning me some of this vitamin/trace elements mixture, $\mathrm{Mr}$ G. A. Paulissen for loaning me some Dicalcium phosphate, and Francis Ubuike who gave very considerable assistance in the field and laboratory. This paper represents a modification of material used in a $\mathrm{Ph}$. D. thesis. The study was partly financed by a grant from the University of Ibadan Senate Research Grants Sub-Committee.

\section{REFERENCES}

1. Anadu P. A., 1974: The ecology and breeding biology of small rodents in the derived savanna zone of south-western Nigeria. Ph. D. thesis, University of Ibadan.

2. An a du P. A., 1976: Observations on reproduction and development in Mus (Leggada) musculoides (Rodentia, Muridae). Mammalia, 40: 175-186.

3. Anadu P. A., (In press) (a): A study of small rodent populations in southwestern Nigeria; II. Trends in numbers, breeding activity and population structure of Myomys daltoni (Thomas). J. W. Afr. Sci. Assoz.

4. Anadu P. A., (In press) (b): A study of small rodent population in southwestern Nigeria: I. Trends in numbers, breeding activity and population structure of the pigmy mouse, Mus (Leggada) musculoides Temminck. J. W. Afr. Sci. Assoc.

5. As del1 S. A., 1964: Patterns of Mammalian reproduction (2nd ed.). Constable \& Co. Ltd.: 1-670. London.

6. H a p pold D.C. D., 1975: The effects of climate and vegetation on distribution of small rodents in Western Nigeria. Z. Säugetierkunde, 40: 221-242.

7. Leslie P. H., Perry J. S. \& W a ts on J. S., 1945: The determination of the median body weight at which female rats reach maturity. Proc. Zool. Soc., Lond., 115: 473-488.

8. Owen D. F., 1966: Animal ecology in tropical Africa. Oliver \& Boyd: 1-122. Ediniburgh, London.

9. R es evear D. R., 1969: The rodents of West Africa. Brit. Mus. (Nat. Hist.): $1-604$. London.

Accepted, March 30, 1978. 


\section{P. A. ANADU}

PARAMETRY ROZRODU MYOMYS DALTONI W NATURZE I W NIEWOLI

\section{Streszczenie}

Zbadano następujące parametry rozrodu: wiek, w którym uzyskiwana jest dojrzałość płciowa, wielkość miotu, ilość miotów i śmiertelność prenatalną u zwierząt dzikich i 239 osobników urodzonych w niewoli. Dzikie i hodowlane myszy uzyskują dojrzałość płciową w wieku 18-22 tygodnie, osiągając wówczas średnio ciężar 26,2 g (samce) i $27,5 \mathrm{~g}$ (samice). U osobników dzikich średnia wielkość młodych w miocie równa jest 5,5 a ilość embrionów 3-10 (Tabela 1). Nie stwierdzono wyraźnej korelacji między wiekiem matki a wielkością miotu ale istnieje pewna zależność między sezonem roku a wielkością miotu (Ryc. 1). W warunkach hodowli ilość młodych $\mathrm{w}$ miocie jest istotnie mniejsza bo $1-7$, średnio 3.93 . W hodowli $M$. daltoni rozradza się przez cały rok i od jednej samicy uzyskiwano 9 miotów. Dzikie samice mogą wyprowadzić po 2-3 mioty w dwuletniem akresie aktywności rozrodczej. Jedynie samice biorące udział $w$ rozrodzie $w$ okresie szczytu sezonu mogą produkować 5-6 miotów/rok. Smiertelność prenatalną oszacowano u nich na 23,6\% (Tabela 2). Szczyt płodności uzyskują samice $\mathrm{w}$ drugim $\mathrm{w}$ swoim życiu sezonie rozrodezym. 